\title{
Why There Is a Need for an International Organ to Try the Crime of Terrorism - Past Experiences and Future Opportunities
}

\begin{abstract}
Agata KLecZKowsKA*
Abstract. This paper suggests that the crime of terrorism requires the establishment of an international organ to prosecute the perpetrators of the crime and there is a need to enable the prosecution of the crime of terrorism as a specific new type of international crime. In advancing this thesis, the paper is divided into three parts. The first part briefly defines the notion of terrorism, while the second discusses the international legal instruments and practices when it comes to prosecution of the crime of terrorism. It starts with the first failed attempts to define and prosecute the crime of terrorism. Next, it discusses the jurisdiction of different international courts and tribunals over the crime of terrorism. The third part presents the specific case of the Polish domestic legislation regulating the crime of terrorism in order to demonstrate that States which so far have not been affected in a major way by terrorism may have little experience in creating comprehensive legislation, yet they still may have to deal with perpetrators of the crime. This is why both a comprehensive legal instrument and an international organ with jurisdiction over the crime of terrorism are necessary.
\end{abstract}

Keywords: public international law, terrorism, international crimes, Poland, International Criminal Court

\section{INTRODUCTION}

Terrorism is undoubtedly one of the most dangerous phenomena threatening international peace and security today. According to Our World in Data, there were around 13,500 terrorism-related incidents in $2016^{1}$ and even though this number had slightly decreased over the previous two years, ${ }^{2}$ it is still enormous. Importantly, these incidents affected nearly all parts of the world. However, despite the numbers, no permanent international organ, including also the International Criminal Court (ICC), has jurisdiction over the crime of terrorism. While all international criminal courts have long been able to prosecute crimes against humanity, genocide, and war crimes, only one, the Special Tribunal for Lebanon (STL), was empowered to try perpetrators of the crime of terrorism, and even in that case the STL's jurisdiction over crimes of terrorism was based on domestic law. Comparing the statistics connected with terrorism and number of terrorism-related incidents, it is easy to observe that the problem of terrorism is ignored in the international judicial system.

This paper suggests that the crime of terrorism, which is no less dangerous and much more widespread than other international crimes, requires the establishment of an international organ to prosecute the perpetrators of the crime. The aim of this paper is thus to prove that there is an urgent need to enable the prosecution of the crime of terrorism as a

* Institute of Law Studies, Polish Academy of Sciences, agata.kleczkowska@inp.pan.pl. The research for this article was supported by a grant from the National Science Centre (Poland) awarded for the research project 'Liability for crimes committed by armed non-state actors - domestic and international perspective' (UMO-2016/23/N/HS5/02849).

1 Our World in Data defines terrorism as 'the threatened or actual use of illegal force and violence by a non-state actor to attain a political, economic, religious, or social goal through fear, coercion, or intimidation.' Terrorism (2018), link 6.

2 Our World in Data estimates that in 2014 there were 16,860 terrorism-related incidents. 
specific new type of international crime. In advancing this thesis, the paper is divided into three parts. The first part briefly defines the notion of terrorism, while the second discusses the international legal instruments and practices when it comes to prosecution of the crime of terrorism. It starts with the first failed attempts to define and prosecute the crime of terrorism in the work of the League of Nations and the International Law Commission (ILC). Next, it discusses the jurisdiction of different international courts and tribunals over the crime of terrorism, 'terror', and 'acts of terrorism'. The third part presents the specific case of the Polish domestic legislation regulating the crime of terrorism in order to demonstrate that States which so far have not been affected in a major way by terrorism may have little experience in creating comprehensive and effective legislation in this regard, yet they still may have to deal with perpetrators of the crime. This is why both a comprehensive legal instrument and an international organ with jurisdiction over the crime of terrorism are necessary.

\section{WHAT IS TERRORISM?}

There is no single unanimously accepted definition of terrorism. It is claimed that the most important reason for this state of affairs is that the legal definition of terrorism would in fact be highly politicized, ${ }^{3}$ as what one may consider as terrorism, another may praise as a struggle for self-determination and a fight for national liberation. Thus there is a problem with establishing the scope of the definition and defining which acts should (or should not) be qualified as terrorism. ${ }^{4}$

However, despite the fact that States have been unable to reach universal agreement over how to define terrorism, they have concluded conventions which adopt a 'thematic' approach towards the problem of terrorism; it is estimated that there are between 11 and 14 such legal acts. ${ }^{5}$ In addition, there are also numerous other legal instruments, either regional

3 Cohen (2012) 224-28.

4 van der Vyver (2010) 533.

5 Cryer, Friman, Robinson and Wilmshurst (2010) 339. These conventions are: Convention for the Suppression of Unlawful Seizure of Aircraft (adopted 16 December 1970, entered into force 14 October 1971) 860 UNTS 105; Convention for the Suppression of Unlawful Acts against the Safety of Civil Aviation (adopted 23 September 1971, entered into force 26 January 1973) 974 UNTS 177, together with Protocol for the Suppression of Unlawful Acts at Airports Acts against the Safety of Civil Aviation (adopted 24 February 1988, entered into force 6 August 1989) 1589 UNTS 474; Convention on the Prevention and Punishment of Crimes Against Internationally Protected Persons (adopted 14 December 1973, entered into force 20 February 1977) 1035 UNTS 167; International Convention Against Taking of Hostages (adopted 17 December 1979, entered into force 3 June 1983) 1316 UNTS 205; Convention on the Physical Protection of Nuclear Material (adopted 26 October 1979, entered into force 8 February 1987) 1456 UNTS 101; Convention for the Suppression of Unlawful Acts against the Safety of Maritime Navigation (adopted 10 March 1988, entered into force 1 March 1992) 1678 UNTS 201, with Protocol for the Suppression of Unlawful Acts against the Safety of Fixed Platform located on the Continental Shelf (adopted 10 March 1988, entered into force 1 March 1992) 1678 UNTS 201; International Convention for the Suppression of Terrorist Bombings (adopted 15 December 1997, entered into force 23 May 2001) 2149 UNTS 256; International Convention for the Suppression of Financing Terrorism (adopted 9 December 1999, entered into force 10 April 2002) 2178 UNTS 197; Convention for the Suppression of Acts of Nuclear Terrorism (adopted 13 April 2005, entered into force 7 July 2007) 2445 UNTS 89; Convention on Offences and Certain Other Acts Committed on Board Aircraft (adopted 14 September 1963, entered into force 4 December 1969) 704 UNTS 219; Convention on the Marking of the Plastic Explosives for the 
or soft law, ${ }^{6}$ which define terrorism. However, only the International Convention for the Suppression of Financing Terrorism is considered to have a comprehensive legal definition of terrorism, since its language is flexible enough to also encompass new types of acts of terrorism, including cyber-terrorism. ${ }^{7}$ Thus, according to Article 2 (1) of the Convention for the Suppression of Financing Terrorism, terrorism amounts to:

(a) An act which constitutes an offence within the scope of and as defined in one of the treaties listed in the annex; or

(b) Any other act intended to cause death or serious bodily injury to a civilian, or to any other person not taking an active part in the hostilities in a situation of armed conflict, when the purpose of such act, by its nature or context, is to intimidate a population, or to compel a government or an international organization to do or to abstain from doing any act.

It is beyond the scope of this article to discuss in detail all the definitions of the crime of terrorism included in the legal doctrine and in legal instruments but it should be highlighted that all these definitions claim that the aim of the perpetrator of the crime of terrorism is to spread fear, intimidate the population and to compel an organ to act in a certain way. This finding is important for the following parts of this article.

\section{INTERNATIONAL LEGAL REGULATIONS AND PRACTICE CONCERNING THE CRIME OF TERRORISM}

\subsection{Attempts to Regulate and Prosecute the Crime of Terrorism}

This section presents the first attempts to regulate the crime of terrorism in international legal instruments and to establish an international organ to prosecute this crime.

\subsubsection{Crime of Terrorism and its Prosecution in $1930 \mathrm{~s}$}

The history of regulation of the crime of terrorism and its prosecution finds it origins in the 1930s. In 1934, King Alexander of Yugoslavia was assassinated during a State visit in France. Louis Barthou, the French Minister of Foreign Affairs, who was with the King in his carriage, also died. The assassin fled to Italy, which refused to surrender him as the crime was politically motivated and thus not subject to extradition according to the applicable rules of asylum. As the dispute grew, Yugoslavia accused Hungary of complicity.

Purposes of Detection (adopted 1 March 1991, entered into force 21 June 1998) 2122 UNTS 359; UN Convention on the Safety of the United Nations and Associated Personnel (adopted 9 December 1994, entered into force 15 January 1999) 2051 UNTS 363.

${ }^{6}$ E.g. Arab Convention for the Suppression of Terrorism, adopted under the auspices of the League of Arab States (adopted 22 April 1998, entered into force 7 May 1999); Convention of the Organisation of the Islamic Conference on Combating International Terrorism (adopted 1 July 1999, entered into force 7 November 2002); Directive (EU) 2017/541 of the European Parliament and of the Council of 15 March 2017 on combating terrorism and replacing Council Framework Decision 2002/475/JHA and amending Council Decision 2005/671/JHA; UNGA Res 49/60 (9 December 1994) UN Doc A/RES/49/60; UNSC Res 1566 (28 October 2009) UN Doc S/RES/1566.

7 Cohen (2012) 232-34. 
In response, France proposed creating an International Penal Code and establishing an international criminal court to try the perpetrators of the crime of terrorism. This led to the establishment of a 'Terrorism Committee' in Geneva in 1935 under the auspices of the League of Nations. ${ }^{8}$

The Committee produced the Convention for the Prevention and Punishment of Terrorism. ${ }^{9}$ The Convention defined 'acts of terrorism' as 'criminal acts directed against a State and intended or calculated to create a state of terror in the minds of particular persons, or a group of persons or the general public' [Article 1 (2)]. State Parties to the Convention were obliged not only to refrain from encouraging terrorist activities and to prevent acts 'in which such activities take shape' [Article 1 (1)], but also to introduce changes to their national criminal legislation in order to prohibit 'acts of terrorism' (Article 2). However, terrorism referred only to activities conducted against 'members of the public', including heads of States and their families as well as public property.

Along with these works, the Convention for the Creation of the International Criminal Court was also prepared. ${ }^{10}$ The jurisdiction of the Court was supposed to be limited only to 'persons accused of an offence dealt with in the Convention for the Prevention and Punishment of Terrorism' (Article 1), i.e. the crime of terrorism as defined in this latter Convention. The Court was created as a permanent body, but would sit 'only when it is seized of proceedings for an offence within its jurisdiction' (Article 3). The jurisdiction of the Court could be triggered only by a State Party's submission as States were entitled, 'instead of prosecuting before its own courts, to commit the accused for trial to the Court' [Article 2 (1)]. Consequently, proceedings before the Court were dominated by the State Party that submitted the case to the Court since the Court was bound by the scope of charges brought by a State and could not exercise jurisdiction against any other person(s) than the one accused by the State (Article 27). Moreover, such a State Party was assigned an important role in the proceedings before the Court as according to Art. 25 (3), it was supposed to conduct the prosecution. Interestingly, the Convention for the Creation of the International Criminal Court did not present any catalogue of sources of law which should be applied by the Court, nor contain a list of potential punishments. Instead, Article 21 of the Convention stated that in order to establish the substantive criminal law to be applied in cases before the Court, the Court 'shall take into consideration the law of the territory on which the offence was committed and the law of the country which committed the accused to it for trial' and that when choosing between these two legal systems the Court was ordered to choose 'the least severe' legal system.

The final texts of both Conventions were presented in 1937. By $31^{\text {st }}$ May 1938, nineteen States had signed the convention on terrorism, and thirteen had signed the convention establishing the criminal court. However, neither of these legal acts ever came into force since the only State that ratified the Convention for the Prevention and Punishment of Terrorism was India, while no State ratified the Convention for the Creation of the International Criminal Court. There are different reasons offered for this failure. B. Ferencz claims that

8 Ferencz (1980) 47-54.

${ }^{9}$ League of Nations, Proceedings of the International Conference on the Repression of Terrorism, Geneva November $1^{\text {st }}$ to $16^{\text {th }}, 1937$, Official No.: C.94.M.47.1938.V, 380-88.

10 League of Nations, Proceedings of the International Conference on the Repression of Terrorism, Geneva November $1^{\text {st }}$ to $16^{\text {th }}, 1937$, Official No.: C.94.M.47.1938.V, 389-98. 
during the course of three years following the assassination of King Alexander and Louis Barthou the tempers of public outrage had cooled. Most States were not ready to accept any effective controls or enforced alteration of the past practices. ${ }^{11}$

On the other hand, M. Cherif Bassiouni points out that the reasons behind this failure arose from the world crisis connected with the Spanish war, Italy's invasion in Ethiopia and the increasingly aggressive policy of Germany. ${ }^{12}$

The Court proposed in the Convention for the Creation of the International Criminal Court in fact had a semi-international character. Only a State Party could trigger the jurisdiction of the Court by submitting a domestic case before the Court, and the Court was bound by the scope of the domestic proceedings in terms of the accused and the charges, as well as being required to apply domestic substantive criminal law. On the other hand, the Convention had established the procedure to be used before the Court. The shape of the Court was undoubtedly the result of the political situation in the 1930s. Nevertheless, given the role of the State Parties in the proceedings before the Court, including especially the fact that it was the State Party itself that voluntarily submitted the case to the Court, thus binding the Court as to the scope of the proceeding, it could serve as an interesting modern day solution. If States are afraid that granting an international organ jurisdiction over crime of terrorism committed on their territory and against their citizens would result in the lose control over the punishment of perpetrators of the crime of terrorism, the model proposed in the 1937 Convention for the Creation of the International Criminal Court could balance the interests of States and the competences of the international organ established to prosecute the crime of terrorism. Thus, it would seem that the model offered by the Convention for the Creation of the International Criminal Court should be kept in mind in future considerations concerning the establishment of a competent international tribunal to prosecute perpetrators of the crime of terrorism. What certainly would not pass muster in today's reality is the narrow definition of the crime of terrorism contained in the Convention for the Prevention and Punishment of Terrorism, since it referred only to States' actions, ignoring the actions of private individuals and those belonging to armed non-state actors which are independent from States.

\subsubsection{The Crime of Terrorism in the Works of the ILC's Draft Code of Crimes against the Peace and Security of Mankind}

In the course of its works upon a Draft Code of Crimes against the Peace and Security of Mankind the ILC proposed including the crime of terrorism in the Code. Initially, the 1954 version of the Draft Code prohibited

The undertaking or encouragement by the authorities of a State of terrorist activities in another State, or the toleration by the authorities of a State of organized activities calculated to carry out terrorist acts in another State. ${ }^{13}$

11 Ferencz (1980) 47-54.

12 Bassiouni (1999) 608.

13 Article 2 (6), ILC, 'Draft Code of Offences against the Peace and Security of Mankind' (1954) II Yearbook of the International Law Commission. 
Later, in 1990, this regulation was replaced by the definition of 'international terrorism' in Article $16(1),{ }^{14}$ which described it as:

undertaking, organizing, assisting, financing, encouraging or tolerating by the agents or representatives of a State of acts against another State directed at persons or property and of such a nature as to create a state of terror in the minds of public figures, groups of persons or the general public.

It is important to observe that both the 1954 and 1990 versions defined terrorism only as State activities, which is underlined by the term 'international' used in the 1990 Draft Code. Thus, the ILC wanted to clearly distinguish between 'international' and 'internal' terrorism, with the latter referring to activities 'organized and carried out in the territory of a State by nationals of that State.' According to the ILC, '[i]nternal terrorism comes under internal law, since it does not endanger international relations.' This idea was expressed in Article 16 (2), which refers to '[t]he participation by individuals other than agents or representatives of a State in the commission of any of the acts referred to in paragraph 1', which nevertheless did not cover 'acts of terrorism committed by individuals which have no link with international acts of terrorism as defined in paragraph 1.' As the ILC further observed, 'it has not seemed possible to consider terrorism by individuals as belonging to the category of crimes against peace, to the extent that such activities are not attributable to a State.' 15

When in 1991, the ILC considered the possible scope of the jurisdiction of the international criminal court, the Special Rapporteur claimed that:

[i]t was better to proceed cautiously and flexibly, starting, for example, by restricting the court's jurisdiction to crimes which were dealt with in international conventions, on which general agreement therefore existed, such as genocide, apartheid, certain war crimes, certain acts of terrorism - for instance attacks on persons and property enjoying diplomatic protection - and drug trafficking, which should be listed in an annex to the statute of the Court. ${ }^{16}$

However, States expressed considerable doubts about the inclusion of 'international terrorism' as a separate type of crime in the Draft Code. States questioned 'whether every terrorist act would constitute a crime against the peace and security of mankind or otherwise meet the criteria for the inclusion of crimes in the Code.' Ultimately it was decided that 'international terrorism might constitute a crime against the peace and security of mankind when the terrorist acts were particularly grave and massive in character and that consideration could be given to its inclusion as a crime against humanity.' ${ }^{17}$

As a result, the final version of the Draft Code did not regulate 'international terrorism' as a separate crime, but Art. 20 (f) (iv) stated that a war crime includes '[a]ny of the

14 Later, this article was renumbered to art. 24 (ILC, 'Report of the International Law Commission on the work of its 43rd session' (29 April - 19 July 1991), UN Doc A/46/10 [167]).

15 ILC, 'Report of the International Law Commission on the work of its 42nd session' (1 May - 20 July 1990) UN Doc A/45/10, 28.

16 UN Doc A/46/10 [107].

17 ILC, 'Report of the International Law Commission on the work of its 47th session' (2 May 21 July 1995) UN Doc A/50/10 [106]. 
following acts committed in violation of international humanitarian law applicable in armed conflict not of an international character', including also 'acts of terrorism'. However, it is also important to observe that the ILC considered that a 'policy of terror' may be qualified as organized and systematic attacks which fall under 'acts, when committed in a systematic manner', and so constitute an element of a crime against humanity. ${ }^{18}$

Thus, despite initial attempts to establish the crime of terrorism as a separate type of crime, in the end 'acts of terrorism' were qualified as an element of either war crimes or crimes against humanity. One should also highlight that States had doubts whether all acts of terror were grave enough to be prosecuted or regulated on the international level.

\subsubsection{Summary}

A few preliminary remarks can be drawn from the early attempts to regulate the crime of terrorism in the Convention for the Creation of the International Criminal Court, the Convention for the Prevention and Punishment of Terrorism, and in the ILC's works. It is possible to build up a model of the prosecution of the crime of terrorism that would enable broad States' participation in the proceedings on the international level, making it partially dependent on the States' will and interests. Given the long-lasting problems with defining terrorism, agreeing on the scope of such definition and qualification of certain acts as terrorist acts such solution could please States on one hand, while on the other give the prosecution of the crime of terrorism a more objective, international dimension. Secondly, certainly, an act establishing an organ with jurisdiction over the crime of terrorism should also include a definition of the crime. It is beyond the scope of this article to discuss all the problems connected with defining this crime. However, it should be highlighted here that the crime of terrorism should be defined as a separate, specific type of crime. It has been demonstrated that, due to States' concerns, such a separate regulation of the crime of terrorism was replaced with the concept of making 'acts of terrorism' an element of war crimes and crimes against humanity. It will be demonstrated below that such a solution is definitely not satisfactory even though it is still present in today's discussions over this crime.

\subsection{The Crime of Terrorism in Statutes of International Criminal Courts and Tribunals}

This part starts with a discussion on including the crime of terrorism under the jurisdiction of the only permanent international criminal court in existence today, i.e. the ICC. Next it analyses the regulations and practice of the ad hoc criminal tribunals. It takes particular notice of the STL regulations and practice, which are important for the international jurisdiction over the crime of terrorism. It also mentions the regulations and case law of the International Tribunal for former Yugoslavia (ICTY), International Special Court for Sierra Leone (SCSL) and the Special Tribunal for Rwanda (STR) to demonstrate that the fact that these organs have jurisdiction over 'acts of terrorism' does not amount to jurisdiction over the crime of terrorism in general, since under their statutes and/or jurisdiction, 'terror' and 'acts of terrorism' constitute just another type of act of war directed against civilian population.

18 ILC, 'Draft Code of Crimes against the Peace and Security of Mankind with commentaries', (1996) II (Part Two) Yearbook of the International Law Commission, 47, 53-4. 


\subsubsection{The International Criminal Court (ICC)}

Terrorism was not explicitly included among the crimes under the Court's jurisdiction under the Draft Statute for an International Criminal Court. However, Article 20 of the Draft Statute stated that

The Court has jurisdiction in accordance with this Statute with respect to the following crimes:

(a) The crime of genocide;

(b) The crime of aggression;

(c) Serious violations of the laws and customs applicable in armed conflict;

(d) Crimes against humanity;

(e) Crimes, established under or pursuant to the treaty provisions listed in the Annex, which, having regard to the conduct alleged, constitute exceptionally serious crimes of international concern.

Thus, even if Article 20 did not explicitly mention terrorism, the commentary to this version of the draft suggests that the crime of terrorism would fall under paragraph ' $d$ ' if a 'systematic campaign of terror committed by some group against the civilian population' would be at stake; or under paragraph ' $a$ ' if it could be qualified as 'motivated on ethnic or racial grounds'. ${ }^{19}$ Moreover, six of the Conventions enumerated in Annex A falling under the Court's jurisdiction on the basis of Article 20 (e) concerned acts of terrorism. ${ }^{20}$

The greatest opponent against inclusion of the crime of terrorism into the Rome Statute was the United States. According to the USA, regulation of the crime of terrorism in the Rome Statute could 'impede or undermine the effective prosecution of terrorists in domestic courts.' The United States claimed, inter alia, that 'the Prosecutor is not in a position to conduct investigations of complex terrorist cases as competently as national Governments', since '[s]uch investigations often take many years and considerable resources' and are of 'considerable scale'. Moreover, according to the USA the primacy given to the international investigations over national efforts could lead to a situation whereby the ICC Prosecutor would somehow compete with national investigators. The United States also had serious doubts as to the confidentiality of the sensitive security information that a State would have an obligation to disclose to the ICC Prosecutor investigating the crime of terrorism. ${ }^{21}$

19 ILC, 'Report of the International Law Commission on the work of its 46th session' (2 May 22 July 1994) UN Doc A/49/10, 38, 41.

${ }^{20}$ Among these Conventions there were Convention for the Suppression of Unlawful Seizure of Aircraft, Convention for the Suppression of Unlawful Acts against the Safety of Civil Aviation, International Convention against the Taking of Hostages (adopted 17 December 1979, entered into force 3 June 1983) 1316 UNTS 205, as well as Convention for the Suppression of Unlawful Acts against the Safety of Maritime Navigation with the Protocol for the Suppression of Unlawful Acts against the Safety of Fixed Platforms located on the Continental Shelf. In the course of the Rome Conference, another proposal of definition of terrorism was submitted by India, Sri Lanka and Turkey, and further supported by Barbados, Dominica, India, Jamaica, Sri Lanka, Trinidad and Tobago And Turkey ('Proposal Submitted by India, Sri Lanka and Turkey', UN Doc A/CONF.183/C.1/L.27/Rev.1; 'Proposal Submitted by Barbados, Dominica, India, Jamaica, Sri Lanka, Trinidad and Tobago And Turkey', UN Doc A/CONF.183/C.1/L.71).

21 'Comments Received Pursuant to Paragraph 4 of General Assembly Resolution 49/53 on the Establishment of an International Criminal Court', UN Doc A/AC.244/1/Add.2, [40]-[42], [44], [48]. 
Ultimately, States decided not to regulate the crime of terrorism as a separate type of international crime. One may distinguish seven reasons why States rejected separate regulation of the crime of terrorism. First was the lack of a clear and universally accepted definition. Secondly, according to some States, the crime of terrorism does not constitute a crime of such international concern when compared with war crimes, crimes against humanity, and genocide. Thirdly, States were concerned that if the crime of terrorism were placed under the ICC's jurisdiction, it could become overburdened. Fourthly, there was a fear that inclusion of the crime of terrorism into the Rome Statute would impede its entry into force. Fifthly, the crime of terrorism was, at the time of Rome Conference, already a treaty crime, thus acts of terrorism were subjected to international cooperation. Sixthly, the determination that a crime of terrorism occurred could at times become highly politicized and could impede the ICC's credibility as a judicial organ if the Court was forced to deal with political issues. Finally, the prosecution of crime of terrorism before the national courts was deemed as sufficient. ${ }^{22}$

Thus, under the current Article 5 of the Rome Statute, the Court has jurisdiction over four crimes: the crime of genocide; crime against humanity; war crimes; and crime of aggression. ${ }^{23}$ Given this state of the law, it is argued that there are two options as to how to include the crime of terrorism into the ICC jurisdiction: amending the ICC Statute or by interpreting the elements of the crimes within its jurisdiction so that acts of terrorism could be also included. ${ }^{24}$

When it comes to the first option, the Annex to the Final Act of the United Nations Diplomatic Conference of Plenipotentiaries on the Establishment of an International Criminal Court included Resolution E, which mentioned the crime of terrorism and recommended

that a Review Conference pursuant to Article 123 of the Statute of the International Criminal Court consider the crimes of terrorism and drug crimes with a view to arriving at an acceptable definition and their inclusion in the list of crimes within the jurisdiction of the Court. ${ }^{25}$

Some States believed that, as stated in Resolution E, as soon as the Statute would come into force it would be possible to amend it by adding crimes which were originally not regulated in the Statute, including the crime of terrorism. ${ }^{26}$

Thus, pursuant to Article 123, seven years after the entry into force of the Statute the UN Secretary-General convened a Review Conference. However, during the pre-Conference meetings of the working group, only the Netherlands raised the problem of regulation of the crime of terrorism under the ICC Statute. It observed that apart from national legislations, the crime of terrorism should also be regulated on the international level, in case a State was unwilling or unable to prosecute those guilty of this crime before domestic courts. Thus, the inclusion of the crime of terrorism in the ICC Statute could 'strengthen the arsenal

22 Cassese (2001) 994; Cohen (2012) 223-28.

23 Rome Statute of the International Criminal Court (adopted 17 July 1998, entered into force 1 July 2002) 2187 UNTS 3.

24 Corrales Hoyos (2017) 35-6.

25 'Final Act of the United Nations Diplomatic Conference of Plenipotentiaries on the Establishment of an International Criminal Court', Annex I, UN Doc A/CONF.183/10.

26 Clark (2008) 1751. 
of counter-terrorism measures.' The Netherlands argued that the lack of a uniform definition of terrorism should not be an obstacle to trying the perpetrators of this crime. It suggested that with regard to the crime of terrorism States should proceed in the same way as in the case of the crime of aggression - terrorism should be included in Article 5 of the ICC Statute "with a deferral of the exercise of jurisdiction by the Court until the definition and the modalities for the exercise of such jurisdiction had been agreed to.' At the same time, a working group on terrorism could be established which would discuss all issues important from the standpoint of the ICC's jurisdiction. ${ }^{27}$ Thus Netherlands submitted a proposal for an amendment of Article 5 of the ICC Statute which would add the crime of terrorism under letter ' $\mathrm{e}$ ' to paragraph 1 , as well as add paragraph $3 .{ }^{28} \mathrm{In}$ its summary of the discussion before the First Review Conference, the Netherlands observed that

no delegation had indicated that the crime of terrorism should not fall within the jurisdiction of the Court, and its non-inclusion in the Statute could send the wrong signal that there was no agreement that terrorism was a very serious crime that should fall under the jurisdiction of the Court. ${ }^{29}$

In the end, terrorism was not put on the list of items included in the provisional agenda of the Review Conference ${ }^{30}$ and was not discussed during the Conference. Nevertheless, if States wish to launch works on the inclusion of crime of terrorism into the ICC Statute, they may introduce at any time such amendment under Article 121, or convene another Review Conference under Article 123 of the Rome Statute. As for now, there are no signs on the part of States that they are willing to introduce such an amendment to the ICC Statute.

The second way to include the crime of terrorism under the ICC's jurisdiction is by an interpretation of the elements of crimes already falling under the ICC's jurisdiction. Thus, certain acts of terrorism, if they fulfil some additional criteria, may be qualified as a crime against humanity, a war crime or genocide.

First of all, in the ILC's works and during the Rome Conference there were suggestions made that acts of terrorism should be interpreted as elements of the crime against humanity. ${ }^{31}$ Such an interpretation is not inconsistent with the historic meaning of a crime against humanity, since the 1919 Versailles Peace Conference Commission explicitly included 'systematic terrorism' as part of a crime against humanity. ${ }^{32}$

27 'Report of the Working Group on the Review Conference - Eighth session', vol I, annex 1, UN Doc ICC-ASP/8/20, [40]-[42].

28 Paragraph 3 was supposed to state that 'The Court shall exercise jurisdiction over the crime of terrorism once a provision is adopted in accordance with Articles 121 and 123 defining the crime and setting out the conditions under which the Court shall exercise jurisdiction with respect to this crime. Such a provision shall be consistent with the relevant provisions of the Charter of the United Nations' ('Report of the Working Group on the Review Conference - Eighth session', vol I, annex 1, UN Doc ICC-ASP/8/20, Appendix III: Netherlands).

29 'Report of the Working Group on the Review Conference - Eighth session', vol I, annex 1, UN Doc ICC-ASP/8/20 [51].

30 'Annotated list of items included in the provisional agenda' (12 May 2010) UN Doc RC/1/ Add.1.

31 van der Vyver (2010) 538-39.

32 Hall (2008) 167. 
Article 7 (1) of the ICC Statute, which defines a crime against humanity, states as follows: 'For the purpose of this Statute, 'crime against humanity' means any of the following acts when committed as part of a widespread or systematic attack directed against any civilian population, with knowledge of the attack (...)'. Thus, commentators highlight the convergence between the 'widespread and systematic' character of acts of terrorism and the definition of a crime against humanity. The requirement of 'widespread or systematic' attacks excludes isolated criminal acts from the ICC's jurisdiction, it nevertheless does not establish a very high threshold to fulfil these criteria e.g., previous legal instruments mentioned 'large scale' and 'mass scale' attacks rather than 'only' 'widespread'. On the other hand, 'any civilian population' means that not the entire population must be subjected to the attack. ${ }^{33}$ Consequently, there are virtually no obstacles against qualifying acts of terrorism under the elements of a crime against humanity.

Attention should be also paid to Article 7 (2) (a), which states that an '[a]ttack directed against any civilian population' means 'a course of conduct involving the multiple commission of acts referred to in paragraph 1 against any civilian population, pursuant to or in furtherance of a State or organizational policy to commit such attack.' Thus, an attack must be committed in pursuance of a policy but, as may be implied from this definition, it does not have to be a State's policy but may be also the policy of a non-state actor. ${ }^{34}$

The most well-known case when the crime of terrorism was discussed as potentially qualifying as a crime against humanity was that of the 9/11 attacks. Some authors argued that if the ICC Statute was already in force at the time of the attacks, ${ }^{35}$ these acts of terrorism should be tried as a crime against humanity, pointing out the 'widespread and systematic' character of the attacks directed against a 'civilian population'. Nico Schrijver claimed that

in the view of their advance planning, large-scale nature and intentional targeting of thousands of innocent civilians, there can be little doubt indeed that these attacks meet the description of a 'widespread or systematic attack against any civilian population' in the chapeau of Article 7 of the Rome Statute, and contain the features of 'murder', 'extermination' or 'other inhumane acts', as included in the list of crimes within the purview of crimes against humanity. ${ }^{36}$

Alain Pellet was also favourably inclined towards this conception. ${ }^{37}$ The opposite view was presented by William A. Schabas, who pointed out that the term 'crime against humanity' used to describe the $9 / 11$ attacks 'has tended to be simplistic and, in the final analysis, superficial' since 'it hinges on what is essentially a literal reading of the definition

33 Dixon (as revised by Christopher K. Hall) (2008) 178-80.

34 Dixon (as revised by Christopher K. Hall) (2008) 236. However, as William A. Schabas highlights, in the past it was considered that a crime against humanity required 'state policy' element. Nevertheless, in the Tadic case, the ICTY's Trial Chamber decided that crime against humanity requires 'a governmental, organizational or group policy' rather than only 'state policy' (Prosecutor $v$. Tadic (Opinion and Judgement) IT-94-1-T (9 May 1997) [644]). Such development was included in art. 7 (2) (a) of the ICC Statute but the Elements of Crimes do not elaborate on that; especially they do not explain whether crime against humanity could be applicable to terrorist acts committed by non-state actors (Schabas (2004) 257-59.

35 The Statute entered into force on 1 July 2002.

36 Schrijver (2001) 289.

37 Pellet (2001) 12. 
of crimes against humanity that appears in Article 7(1) of the Rome Statute of the International Criminal Court' which would make it possible to attribute the charge of a crime against humanity to any serial killing. Schabas further claimed despite the crime of terrorism being explicitly excluded from the ICC Statute does not mean that certain acts cannot be subject to ICC jurisdiction. For instance, certain acts that terrorize civilians may be qualified as elements of crimes against humanity, war crimes, or genocide; however, terrorist acts are not 'by definition' any of these crimes. As a result, qualifying a terroristic act as a crime against humanity due to the 'widespread' and 'systematic' character of the attack is not enough. ${ }^{38}$ Antonio Cassese also observed that

[i]t is perhaps plausible to contend that large-scale acts of terrorism showing the atrocities and features of the attacks of 11 September, or similar to those attacks, fall under the notion of a crime against humanity as long as they meet the requirements of that category of crimes (whereas no special account should be taken of one of the specific features of terrorism, namely the intent to spread terror among civilians). ${ }^{39}$

Thus, some acts of terror could be tried under the ICC Statute as fulfilling some of the elements of a crime against humanity, as long as the special intent behind the acts of terrorism, i.e. spreading terror among the population, is ignored as it is not an element of a crime against humanity.

Similar conclusions may refer to two other crimes under the ICC Statute. When it comes to war crimes, it is argued that if acts of terrorism amount to the 'taking of hostages' during an armed conflict, they may be tried as a war crime ${ }^{40}$ under Article 8 (2) (vii) of the ICC Statute. This viewpoint is supported by the definition included in the ICC Elements of Crime, which reiterates elements of the crime of hostage-taking from Article 1 (1) of the International Convention Against the Taking of Hostages, mentioned above as one of the 'terrorist conventions'. However, while the first part of the definition of 'hostage-taking' from these documents coincides by stating that

[a]ny person who seizes or detains and threatens to kill, to injure or to continue to detain another person (hereinafter referred to as the "hostage") in order to compel a third party. Namely, a State, an international intergovernmental organization, a natural or juridical person, or a group of persons, to do or abstain from doing any act as an explicit or implicit condition $(. . .)^{41}$

38 Schabas (2004) 255-56.

39 Cassese (2001) 995. One the other hand, M. Cherif Bassiouni proposed the specialized international convention concerning the crime against humanity which would encompass forms of terrorism, 'committed by an 'organization' which, on the basis of a 'policy', engages in 'widespread' or 'systematic' attack upon 'a civilian population', by means of killing and other specified acts' [Bassiouni (2002) 90].

40 van der Vyver (2010) 540-41.

41 Article 1 (1) of the International Convention Against the Taking of Hostages. The first three elements of the crime of hostage taking under the ICC Elements of Crime are: ' 1 . The perpetrator seized, detained or otherwise held hostage one or more persons. 2. The perpetrator threatened to kill, injure or continue to detain such person or persons. 3. The perpetrator intended to compel a State, an international organization, a natural or legal person or a group of persons to act or refrain from acting as an explicit or implicit condition (...)' (ICC, 'Elements of Crimes', UN Doc. ICC-ASP/1/3). 
The purpose of the crime as established in these two definitions differs. The ICC Elements of Crime require that the perpetrator should intend to compel a State or other entity to act in a certain way as a condition 'for the safety or the release of such person or persons', while the International Convention Against the Taking of Hostages refers simply to an act performed in exchange 'for the release of the hostage'. Given the experiences of the Second World War, the drafters of the ICC Statute decided that the definition from the Convention is too narrow and thus added the specific mental element of 'intent'. ${ }^{42}$

However, despite some terrorist acts could be tried in theory under the qualification of war crimes as established in the ICC Statute, in practice it turns out to be hardly possible or would constitute simply an erroneous qualification. First of all, only one of the forms of perpetrating the crime of terrorism, that is taking hostages, could be qualified as a war crime. Secondly, to become a war crime, the hostage taking would have to occur during an armed conflict, ${ }^{43}$ which is highly unlikely. Thirdly, as in the case of crimes against humanity, the qualification of hostage-taking as an act of terrorism under the war crimes qualification ignores the most important and the most characteristic element of the crime of terrorism, i.e. the intent to spread terror. This makes this qualification inapplicable.

Finally, it is claimed that acts of terrorism may be qualified also as a genocide if they are committed with a special intent, ${ }^{44}$ which is 'to destroy, in whole or in part, a national, ethnic, racial or religious group' (Art. 6 of the ICC Statute). Thus, acts of terrorism would have to be aimed at destroying such a group if they were to be tried as genocide. The question is whether such 'genocidal' intent may be reconciled with the most characteristic mental element behind the crime of terrorism, i.e. to spread terror. Thus, if the aim of terrorism is to spread fear among a population would it be possible at the same time that the purpose of terrorist act was to destroy this population? Hence, once again the qualification of acts of terrorism as genocide would be possible only by ignoring or rejecting the special intent behind the crime of terrorism.

In addition to all these doubts, the nullum crimen sine lege principle and Art. 22 (2) of the Rome Statute, ${ }^{45}$ which states that ' $[\mathrm{t}]$ he definition of a crime shall be strictly construed and shall not be extended by analogy.' should also be considered. Thus, a person subject to investigation or prosecution should be ensured that it is subjected only to 'legislatively and not to judicially defined crimes, ${ }^{46}$ the latter of which would be the case if, for example, a war crime was expansively interpreted to include an act of terrorism. Thus, if the ICC were to try a perpetrator of the crime of terrorism, it could be viewed as an infringement of the nullum crimen sine lege principle.

In this context, it is also important to bear in mind that the final provisions of the ICC Statute were preceded by long-lasting negotiations, also with respect to the crimes included under ICC jurisdiction. The consent of the State Parties was thus essential at every step of

42 Dörmann (2008) 321. Moreover, one should also observe that the ICC Elements of Crime require that the hostage taking must be committed against 'person or persons [who] were protected under one or more of the Geneva Conventions of 1949' (par. 4), which additionally narrows the group of the victims of the potential act of terrorism.

43 The ICC Elements of Crime explicitly require both that ' $[t]$ he perpetrator was aware of the factual circumstances that established that protected status' (par. 5), as well as that ' $[\mathrm{t}]$ he conduct took place in the context of and was associated with an international armed conflict' (par. 6).

44 Zimmermann (2008) 131.

45 Cohen (2012) 240.

46 Broomhall (2008) 724. 
the creation of this legal act. ${ }^{47}$ Consequently, if the Court were to now commence to discretionally apply the provisions of the Statute so to include acts of terrorism into the current framework of the Statute, States could come to the conclusion that the Court is acting against their interests and beyond its competences.

Despite the proposals in the legal doctrine, acts of terrorism should not be tried under the ICC Statute given the current framework of its jurisdiction. Some acts of terrorism could be qualified as a crime against humanity, a war crime or genocide, but none of these qualifications would reflect the special intent behind the crime of terrorism, which would lead to an overly simplistic categorization of this crime. To conclude, under the current regulations of the ICC Statute there is no basis for trying the perpetrators of the crime of terrorism.

\subsubsection{The Special Tribunal for Lebanon (STL)}

The first ad hoc criminal tribunal which was explicitly authorised to prosecute the crime of terrorism was the Special Tribunal for Lebanon, ${ }^{48}$ which was formed in order to 'to try all those who are found responsible for the terrorist crime which killed the former Lebanese Prime Minister Rafik Hariri and others. ${ }^{49}$ However, what was special about this Tribunal was not only the scope of its jurisdiction rationae materiae, but also that the STL was supposed to apply the domestic criminal law of Lebanon in order to prosecute the crime of terrorism. Article 2 of its Statute stated that

The following shall be applicable to the prosecution and punishment of the crimes referred to in article 1, subject to the provisions of this Statute:

(a) The provisions of the Lebanese Criminal Code relating to the prosecution and punishment of acts of terrorism, crimes and offences against life and personal integrity, illicit associations and failure to report crimes and offences, including the rules regarding the material elements of a crime, criminal participation and conspiracy; and (b) Articles 6 and 7 of the Lebanese law of 11 January 1958 on 'Increasing the penalties for sedition, civil war and interfaith struggle. ${ }^{50}$

It is beyond the scope of this article to analyse the case law of the STL in detail. However, it is indispensable to mention here one of the statements made by the STL on the mutual relationship between domestic and international regulations of the crime of terrorism.

In 2011, the Pre-Trial Judge submitted to the Appeals Chamber fifteen questions of law that required resolution before the Pre-Trial Judge could determine whether to confirm the indictment in the case of Ayyash et al. The answer to these questions highlighted many

47 Herik (2014) 5.

48 Ventura (2011) 1022.

49 Statute of the Special Tribunal for Lebanon (adopted 30 May 2007 UNSC Res 1757) UN Doc S/RES/1757, preamble.

50 Article 314 of the Lebanese Criminal Code states that 'Terrorist acts are all acts intended to cause a state of terror and committed by means liable to create a public danger such as explosive devices, inflammable materials, toxic or corrosive products and infectious or microbial agents'. Thus, under Lebanese law, the definition of terrorism consists of two part: a crime of terrorism amounts to first of all, any act, if secondly, it is committed in order to create public danger (Ambos (2011) 660). 
important issues relevant from the general perspective of regulation of the crime of terrorism, even if the Appeals Chamber's decision turned out to be very controversial on many points. First of all, the Appeals Chamber observed that even though the STL is said to apply primarily the domestic Lebanese law, ${ }^{51}$ it is also a tribunal of an international character' and thus is obliged to take into account international standards of justice. Moreover, its Statute incorporates some elements of international criminal law, which is especially true with regard to Article 3 of the Statute. In addition, the provisions of the Statute should be read in the context of Lebanon's international obligations. Thus, the STL must take into account the relevant international legal regulations, both of a treaty and customary nature as international law may provide guidance on how to interpret the Lebanese Criminal Code. This approach is not contrary to the fact that the STL should apply the law as interpreted and applied by Lebanese courts: given that international law also influences the way the Lebanese domestic law is construed, the interpretation of Lebanese Criminal Law in the way Lebanese domestic courts would do so requires also taking into account the international law which is binding on Lebanon. Moreover, when it comes to the interpretation of the Statute, the Tribunal should refer to international rules of interpretation, regardless of whether the STL Statute is deemed to be part of an international agreement between Lebanon and the United Nations, or as part of a binding resolution adopted by the UN Security Council under Chapter VII of the UN Charter, the international rules of interpretation are applicable to each such binding instrument. ${ }^{52}$ In the most controversial part of the decision, ${ }^{53}$ the STL came to the conclusion that

a number of treaties, UN resolutions, and the legislative and judicial practice of States evince the formation of a general opinio juris in the international community, accompanied by a practice consistent with such opinio, to the effect that a customary rule of international law regarding the international crime of terrorism, at least in lime of peace, has indeed emerged. This customary rule requires the following three key elements: (i) the perpetration of a criminal act (such as murder, kidnapping, hostagetaking, arson, and so on), or threatening such an act; (ii) the intent to spread fear among the population (which would generally entail the creation of public danger) or directly or indirectly coerce a national or international authority to take some action, or to refrain from taking it; (iii) when the act involves a transnational element. ${ }^{54}$

In summary, a few lessons may be learnt from the STL regulations and practice. First of all, as in case of the Convention for the Creation of the International Criminal Court, the domestic legislation was used once again to prosecute the crime of terrorism at the international level. It could be argued that this solution was not verified in case of the Convention for the Creation of the International Criminal Court, as the Court based on the Convention was never established in practice. However, the example of the STL proves that this solution is realistic and feasible. Secondly, the STL clearly highlighted that the regulations of domestic Lebanese criminal law must be interpreted through the prism of

51 Interlocutory Decision on the Applicable Law: Terrorism, Conspiracy, Homicide, Perpetration, Cumulative Charging, STL-11-O1/I (16 February 2011) [33].

${ }^{52}$ STL-11-O1/I, par. [15]-[16], [20], [22], [26], [35], [41], [44]-[45], [114].

53 Ventura (2011) 1027. For the critical approach towards the Interlocutory decision see Ambos (2011) 655-75, as well as Saul (2011) 677-700.

54 STL-11-O1/I, [85]. 
international law, which adds an international dimension to the domestic regulation of the crime of terrorism used before an international organ. Finally, the most interesting, although also the most controversial part of the Appeals Chamber answer to the Pre-Trial Judge, concerned the customary character of the crime of terrorism and the definition of this crime under customary law. The definition proposed by the Appeals Chamber of the STL is very inclusive but at the same time encompasses all the elements discussed in the doctrine of law and mentioned in legal acts. Moreover, apart from being a very interesting proposal for defining the crime of terrorism, it also suggests that States' practice and opinio juris support the finding that the crime of terrorism is already regulated by international customary norms as a separate crime.

\subsubsection{The International Criminal Tribunal for Rwanda (ICTR)}

Under Article 4 (d) of the Statute of the ICTR, the International Tribunal for Rwanda

shall have the power to prosecute persons committing or ordering the commission of serious violations of Article 3 common to the Geneva Conventions of 12 August 1949 for the Protection of War Victims, and of Additional Protocol II thereto of 8 June 1977. These violations shall include, but shall not be limited to: (...) (d) Acts of terrorism. ${ }^{55}$

None of the cases before the ICTR concerned the commission of 'acts of terrorism'. However, bearing in mind that Art. 4 (d) of the ICTR Statute established a crime with regard to the breach of certain legal acts, it is worthwhile to analyse the regulations of the Additional Protocol II (ADII), which refer to 'acts of terrorism' and 'terror', to better understand the meaning of Art. 4 (d) of the ICTR Statute. ${ }^{56}$

Article 4 of the ADII refers to persons 'who do not take a direct part or who have ceased to take part in hostilities'. The first paragraph obliges all parties to a conflict to treat such persons humanely, while the second paragraph prohibits certain specific behaviours towards them, including the commission of 'acts of terrorism'. ${ }^{57}$ The regulation contained in Art. 4 (2) (d) reflects Art. 33 of the Fourth Geneva Convention, making this prohibition applicable also to non-international armed conflicts. However, the formula used in Art. 4 (2) (d) of ADII is broader then in the Fourth Geneva Convention, as it 'covers not only acts directed against people but also acts directed against installations which would cause victims as a side-effect. ${ }^{58}$ It should also be mentioned that Art. 13 (2) of the ADII states

55 Statute of the International Criminal Tribunal for the Prosecution of Persons Responsible for Genocide and Other Serious Violations of International Humanitarian Law Committed in the Territory of Rwanda and Rwandan Citizens Responsible for Genocide and Other Such Violations Committed in the Territory of Neighbouring States (adopted 8 November 1994, entered into force 29 June 1995) UN Doc S/RES/955.

56 Article 3 of Geneva Conventions does not mention 'acts of terrorism', Convention (I) for the Amelioration of the Condition of the Wounded and Sick in Armed Forces in the Field. Geneva, 12 August 1949 (adopted 12 August 1949, entered into force 21 October 1950) 75 UNTS 287.

57 'Without prejudice to the generality of the foregoing, the following acts against the persons referred to in paragraph 1 are and shall remain prohibited at any time and in any place whatsoever: (...) acts of terrorism' (Protocol additional to the Geneva Conventions of 12 August 1949, and relating to the protection of victims of non-international armed conflicts (Protocol II) (adopted 8 June 1977, entered into force 7 December 1978) 1125 UNTS 609.

58 Junod (1987) 1375. 
that ' $[\mathrm{t}]$ he civilian population as such, as well as individual civilians, shall not be the object of attack. Acts or threats of violence the primary purpose of which is to spread terror among the civilian population are prohibited.' Thus, Art. 13 (2) prohibits attacks aimed at terrorizing the civilian population as one of the types of prohibited attacks. ${ }^{59}$

The ICTR could have tried the 'acts of terrorism' committed during the noninternational armed conflict in Rwanda but only these attacks which were directed against civilians or could have side-effects that affected civilians. Thus, the 'acts of terrorism' were included under the ICTR jurisdiction only as a part of acts of war against the protected persons, and not as a separate crime with universal application, regardless of the state of the armed conflict.

\subsubsection{The Special Court for Sierra Leone (SCSL)}

A very similar regulation as that in the Statute of the ICTR was included in the Statute of the SCSL. Article 3 (d) of the its Statute states that

The Special Court shall have the power to prosecute persons who committed or ordered the commission of serious violations of article 3 common to the Geneva Conventions of 12 August 1949 for the Protection of War Victims, and of Additional Protocol II thereto of 8 June 1977. These violations shall include: (...) d. Acts of terrorism. $^{60}$

Consequently, the remarks invoked above with regard to ICTR Statute can be referred also to this regulation.

However, in contrast to the ICTR practice, there is some SCSL case law which refers to acts of terrorism. Charles Taylor was one of the defendants accused of, inter alia, acts of terrorism under Article 3 (d) of the SCSL Statute. The Court stated that three elements of 'the crime of acts of terrorism' must be proven beyond a reasonable doubt to establish the guilt of the accused:

i. Acts or threats of violence directed against persons or their property; ii. The perpetrator wilfully made persons or their property the object of those acts and threats of violence; and iii. The acts or threats of violence were committed with the primary purpose of spreading terror among protected persons.

Moreover, 'spreading terror must be the primary purpose of the acts or threats of violence', but 'it need not be the only purpose'. ${ }^{61}$ The SCSL found that murders, the burning of civilian property, rape, sexual slavery, forced marriages, outrages on personal dignity, amputations, carving the names of armed groups on bodies and disfigurement may be qualified as 'acts of terrorism'. ${ }^{62}$

59 Junod (1987) 1453.

60 Statute of the Special Court for Sierra Leone (adopted 14 August 2000) UN Doc S/RES/1315.

61 Prosecutor v. Charles Ghankay Taylor (Judgement) SCSL-03-01-T (18 May 2012) [403], [405].

62 Prosecutor v. Charles Ghankay Taylor (Judgement) SCSL-03-01-T (18 May 2012) [1979], [2006], [2017], [2021], [2035], [2044], [2046]. 
Thus, the definition of 'acts of terrorism' applied by the SCSL includes the most frequently repeated elements of the crime of terrorism and can be of universal application. However, as in case of the ICTR the 'acts of terrorism' placed under the SCSL's jurisdiction concerned the non-international armed conflict, and were included in the SCSL Statute through the prism of regulations relating to this type of armed conflict.

\subsubsection{The International Criminal Tribunal for Yugoslavia (ICTR)}

The ICTY, contrary to the STL, ICTR and SCSL, under its Statute explicitly had no jurisdiction over terrorism or 'acts of terrorism'. However, the ICTY found a way to prosecute the offence of terror through Article 3 of its Statute which was deemed to be 'a residual clause which covers all serious violations of humanitarian law not covered by Articles 2, 4 or 5 of the Statute' ${ }^{63}$ Thus, Article 3 states as follows:

The International Tribunal shall have the power to prosecute persons violating the laws or customs of war. Such violations shall include, but not be limited to:

(a) employment of poisonous weapons or other weapons calculated to cause unnecessary suffering;

(b) wanton destruction of cities, towns or villages, or devastation not justified by military necessity;

(c) attack, or bombardment, by whatever means, of undefended towns, villages, dwellings, or buildings;

(d) seizure of, destruction or wilful damage done to institutions dedicated to religion, charity and education, the arts and sciences, historic monuments and works of art and science;

(e) plunder of public or private property. ${ }^{64}$

It is claimed that the first case in which the ICTY tried the offence of terror was Prosecutor v. Stanislav Galic, ${ }^{65}$ where the Tribunal declared that:

(...) the Majority is not required to decide whether an offence of terror in a general sense falls within the jurisdiction of the Tribunal, but only whether a specific offence of killing and wounding civilians in time of armed conflict with the intention to inflict terror on the civilian population, as alleged in the Indictment, is an offence over which it has jurisdiction. ${ }^{66}$

Ultimately, the ICTY found that it had jurisdiction over the 'offence of terror'. ${ }^{67}$ Regarding the jurisdiction over this crime under the ICTY Statute, the Tribunal decided that 'the crime of terror against the civilian population in the form charged in the Indictment is constituted of the elements common to offences falling under Article 3 of the Statute,' as

63 Prosecutor v. Dragomir Milošević (Judgement) IT-98-29/1-T (12 December 2007) [870].

${ }^{64}$ Statute of the International Criminal Tribunal for the Former Yugoslavia (adopted 25 May 1993 UNSC Res 827).

65 van der Vyver (2010) 542-43.

66 Prosecutor v. Stanislav Galić (Judgement) IT-98-29-T (5 December 2003) [87].

67 Prosecutor v. Stanislav Galić (Judgement) IT-98-29-T (5 December 2003) [131]. 
well as of the specific elements, repeated and developed thereafter in the Prosecutor v. Charles Taylor judgement. ${ }^{68}$

The ICTY found that its task was not to try (or even consider if it could try) perpetrators of the crime of terrorism committed at any time, but that it could, under Article 3 of its Statute, adjudicate specific cases of terror as a type of measure applied against the civilian population during an armed conflict, as they were violations of 'the laws or customs of war'. As a result, the ICTY ruled out the solution which has been discussed with respect the ICC's jurisdiction over the crime of terrorism, as it decided that, under its Statute it may try 'terror' only as one of the types of prohibited attacks occurring during an armed conflict and not as a separate crime.

\subsubsection{Summary}

The above analysis has demonstrated that there is both a need and a way to regulate the crime of terrorism as a separate crime and establish the jurisdiction of an international organ over it. Drawing on the experiences of the past tribunals and drafted documents, it can be concluded that a new, international body should be created. It would have jurisdiction over cases of the crime of terrorism as a separate kind of crime only if such cases would be referred to it by States (hereinafter: referring States). During the proceedings before such an organ, referring States would perform the role of prosecutor and determine the scope of the adjudication. Certainly, the creation of such an organ would require a new, comprehensive definition of terrorism. It can be argued that such a definition has been formed on the grounds of customary law; however, it should also be incorporated into treaty law to satisfy the standards of criminal proceedings and especially the application of the nullum crimen sine lege principle. In other aspects of the proceedings, the international organ would exercise jurisdiction using the domestic criminal law of the referring State, e.g., when it comes to the penalization of the crime of terrorism. Nevertheless, the domestic law of the referring State would have to be interpreted from the perspective of the international obligations of that State. The jurisdiction of an international organ should concern first and foremost the crime of terrorism committed in a time of peace.

The STL has proven that the crime of terrorism as regulated under domestic law can also become the grounds for jurisdiction of an international (or hybrid) organ. Nevertheless, as the following part demonstrates, not all States' legislation meets the international standards, which could give rise to additional confusion when it comes to the qualification of certain acts as constituting the crime of terrorism. Thus, the next part of this article serves as a further incentive for the creation of new international organ for adjudication of the crime of terrorism.

\section{THE CRIME OF TERRORISM UNDER POLISH CRIMINAL LAW}

Poland is a State which is less likely to be affected by terrorism. ${ }^{69}$ However, this does not mean that Poland does not have to deal at all with the problem of prosecution of the crime of terrorism. Thus, the aim of this part of the paper is to demonstrate how Polish legislation regulates this crime, which may serve as a general example of how States that have little experience in prosecution of the crime of terrorism handle this issue.

68 Prosecutor v. Stanislav Galić (Judgement) IT-98-29-T (5 December 2003) [133].

69 See link 3. 


\subsection{Punishing Acts of Terrorism under Polish Criminal Law}

In total, there are nine articles of the Polish Criminal Code that regulate different aspects of the crime of terrorism. However, three articles, namely $115 \S 20,258 \S 2$ and 141, are of special importance for the topic of this paper. ${ }^{70}$ Article $115 \S 20$, includes the definition of a 'terrorist offence': 71

A terrorist offence is a prohibited act with a sentence of imprisonment for at least five years, committed with the aim of:

1) seriously terrorising a large number of people;

2) forcing a public authority of the Republic of Poland, or another state or international organisation, to take or not to take a certain course of action;

3) causing a serious disturbance in the political system or the economy of the Republic of Poland, or of another state or international organisation.

- Or a threat to commit such an act.

Consequently, there is a 'terrorist offence' if the perpetrator committed an act prohibited by the Criminal Code which is subject to imprisonment for at least five years (the formal element); and did so in order to achieve one of the aims established in Article $115 \S 20$ (the material element). ${ }^{72}$ It stems from this that a 'terrorist offence' is not a sui generis crime but it can be any act prohibited by the Criminal Code, ${ }^{73}$ provided that it is subject to punishment for at least five years and the perpetrator committed it with requisite aim.

It is estimated that around 200 types of offences regulated under Polish criminal law fulfil the formal criterion of a 'terrorist offence' 74 and it is only the intent of the perpetrator that could narrow this group. Thus, out of these 200 offences around 13 could potentially fit into the modus operandi of terrorists. ${ }^{75}$ An example of an offence which potentially could be designated as a 'terrorist offence' would be causing a life-threatening event, regulated by Article 163 of the Penal Code, if committed for example to force the Polish government to take a certain course of action, since if such an action results in the death of a human being or grievous bodily harm to many people, according to the statutory regulation the offender is liable to imprisonment from 2 up to 12 years (Article $163 \S 3$ ).

The provisions of Article $115 \S 20$ are the result of the implementation into the Polish legal system of the Council Framework Decision of 13 June 2002 on combating terrorism. ${ }^{76}$

70 The other seven regulations are Article $65 \S 1$, Article $110 \S 1$; Article 165a; Article 240; Article 255a; Article 259a and Article 259b.

71 All the quotations of the Polish Criminal Code in English come from the translation of the Code as published in the Legalis - System Informacji Prawnej [Legalis - the System of Legal Information], run by the C.H. Beck.

72 Zgorzały (2007) 66.

73 Sońta (2005) 15.

74 Wiak (2015) 757-58.

75 Sońta (2005) 9.

76 On 15 March 2017, the European Parliament and the Council adopted Directive (EU) 2017/541 on combating terrorism and replacing Council Framework Decision 2002/475/JHA and amending Council Decision 2005/671/JHA (OJ L 88, 31.3.2017, p. 6-21). However, the definition of terrorist offence from Art. 3 (1) of the Directive is nearly identical with the one from Council Framework Decision and did not prompt any changes to Article $115 \S 20$ of the Polish Criminal Code. 
However, the way the Framework Decision was implemented in Poland has been subjected to criticism. It is claimed that the definition of 'terrorist offence' contained in Article $115 \S$ 20 is too narrow and does not embrace all the acts enumerated in the Framework Decision, e.g., research into or development of biological or chemical weapons. Moreover, the Polish Criminal Code should not refer to the severity of the punishment, as doing so may exclude acts which otherwise could be qualified as terrorist offences owing to the intent behind the criminal conduct of the perpetrator. However, at the same time, the Polish definition is too wide as potentially any prohibited act which fulfils the formal criterion can be labelled as a 'terrorist offence'. According to the Framework Decision definition, it should refer only to acts which 'given their nature or context, may seriously damage a country or an international organisation where committed.' 77 This was also the opinion expressed in the Report of the Commission on the implementation of the Decision - the Commission registered a few objections to the implementation of the Framework Decision in Poland, mentioning, inter alia, that Article $115 \S 20$ only defines a terrorist intent. ${ }^{78}$

Article 258 of the Polish Criminal Code should also be mentioned as it stipulates the elements of the crime of participation in an organized criminal group:

$\S 1$. Anyone who participates in an organised group or association whose purpose is to carry out criminal offences is liable to imprisonment for three months to five years;

$\S 2$. If the group or association specified in $\S 1$ uses weapons or have terrorist aims, then the offender is liable to imprisonment for six months to eight years;

$\S 3$. Anyone who sets up or leads a group or association specified in $\S 1$ that uses weapons, is liable to imprisonment for between one and 10 years;

$\S 4$. Anyone who sets up or leads a group or association with the intention of carrying out a terrorist attack is liable to imprisonment for at least three years.

Thus, participation in an organized criminal group that has 'terrorist aims' may be penalized under Art. 258 of the Criminal Code. However, it worth noting that the Polish Criminal Code includes one more regulation which may be applied in cases where a Polish national participates in the structures of a terrorist organization. This is Art. 141, which reads as follows:

Art. 141. Service in a foreign army.

$\S 1$. Any Polish national who undertakes military duties in a foreign army or military organisation without authorisation from a relevant authority is liable to imprisonment for between three months and five years.

$\S 2$. Anyone who assumes duties in a mercenary military service prohibited by international law is liable to imprisonment for between six months and eight years.

$\S 3$. A Polish national who is also a national of another state does not commit the offence specified in $\S 1$ if he or she resides in the latter state and completes his or her military service there.

Under this regulation, 'undertaking military duties' also includes undertaking duties in a military formation which is not a part of the armed forces of another State, but nevertheless

77 Nowak (2013) 149.

78 Report from the Commission based on Article 11 of the Council Framework Decision of 13 June 2002 on combating terrorism (/* COM/2007/0681 final */). 
amount to military service, while 'foreign military organization' also includes paramilitary organizations. ${ }^{79}$ Thus, these 'military duties' may refer also to such duties within the structure of armed non-state actors. ${ }^{80}$

In fact, the difference between the offences criminalized in articles 258 and 141 of the Polish Criminal Code may turn out to be very vague, as the qualification of these offences depends on the assessment whether the accused participated in a paramilitary organization or in an organized criminal group that has terrorist aims. This differentiation may be especially difficult taking into account the above-mentioned doubts concerning the politicization of the definition of terrorism - a group may be labelled as an organized criminal group by a State because it conducts military activities which under criminal law are nothing more than criminal activities, but for the group itself, its members and supporters it may be a paramilitary organization whose purpose is to carry out combat against the government using all available tools. Drawing a clear distinction between these two types of offences is not any easier also when analysing the elements of both crimes: both a 'foreign military organization' and an 'organized criminal group' that have terrorist aims should be well-organized and have a certain structure. Likewise, in order to impose criminal liability under Article 141 it is enough for a Polish national merely to 'undertake' duties in the military organization, and it is not required that (s)he committed any particular offence while acting as a member of this military organization. Similarly, in the case of an organized criminal group 'participation' in its structure may also mean a mere readiness to undertake any activities connected with the aims of this group, and not actually undertake any particular activities. ${ }^{81}$

So are there any differences between these two offences? The offence stipulated in Article 141 may be committed only by a Polish national, while the 'participation' in an organized criminal group that has terrorist aims concerns any person under Polish jurisdiction. However, if a Polish national is an accused, both these regulations may be applied. Thus, the most notable difference concerns not the elements of these crimes but their penalization, since the offence defined in Article 141 is penalized considerably lighter. Under Article 141, the accused may be liable to imprisonment for between three months and five years while under Article $258 \S 2$ the accused may be liable to imprisonment for between six months to eight years.

\subsection{Polish Case Law}

The Polish judicial system does not have much experience with adjudicating the offences connected with participation in either a terrorist organization or in an armed group in general. Until now, there have only been a few cases concerning activities of members of such groups in the territory of the Republic of Poland, or conducted by Polish nationals outside the territory of Poland. However, it is worth mentioning at least three cases, since they illustrate the problems the Polish administration of justice has to face in these types of cases.

Information provided by the media is not very extensive in this regard and from the scant pieces of available information a Polish prosecutor issued a 'wanted' warrant in 2015 against a Polish citizen who allegedly fought in Syria for Ansar Al Sham, the terrorist

\footnotetext{
79 Hoc (2014) 825.

80 Kiziński (2006) 40.

81 Kalitowski (2014) 1371.
} 
organization linked to Al-Qaeda. Initially he was accused of undertaking duties in a foreign military organization, however the Polish prosecutor's office did not manage to collect enough evidence to prove his engagement in the activities of Ansar Al Sham or the jihadist training he allegedly underwent in Syria. He was released but ultimately in November 2015 this Polish national was arrested again in Jordan. The prosecutor's office decided then to change the initial qualification of the charges and accused him of the participation in organized crime group that had terrorist aims. ${ }^{82}$ The court's proceedings only started in November 2017. ${ }^{83}$

Another well-known case concerned four men coming from Chechnya, who were accused of participation in an organized crime group which supported activities of the Islamic State, by, inter alia, collecting financial resources for their activities. The judgement, which was issued in August 2017, turned out to be a failure of the prosecutor's office - one was acquitted and the most important piece of evidence presented by the prosecutor's office, the transcripts of the conversations between the accused taken from wiretaps, turned out to consist only of summaries not the exact transcripts of their conversations. ${ }^{84}$

The most recent case, reported by media on 7 March 2018, concerned the arrest of an ISIS member who supported the terrorist attacks in Paris in 2015. He was living in Poland in 2016, when he was located by the Polish Internal Security Agency (Agencja Bezpieczeństwa Wewnętrznego) and arrested. In mid-February 2018, the indictment in his case was sent to the court, but information about his arrest was announced for the first time only recently. ${ }^{85}$

To summarize, the Polish regulation of the terrorist offences is far from perfect. There is no single coherent regulation, and the elements of the crime of terrorism are scattered in many parts of the Criminal Code. The criteria which stipulate which offences could be of a terrorist character are too vague, and in addition do not reflect the core elements of this crime. Moreover, at least two legal qualifications of the acts of members of terrorist organizations are possible under Polish Criminal Code, which certainly does not facilitate the conduct of a just and fair trial of the perpetrators of acts of terror.

\section{CONCLUSIONS}

Currently, there is no international criminal organ which has jurisdiction over the crime of terrorism. The present paper demonstrates that there is an urgent need to regulate the crime of terrorism as a separate type of crime and establish the jurisdiction of an international organ over this crime. It suggests that the model for such a court and its accompanying jurisdiction should be based on the Convention for the Creation of the International Criminal Court and on the practice of international courts, especially the STL. Even though some States regulate the elements of the crime of terrorism in their national legislation, there is still a need for a universal instrument of international law since, as the Polish example shows, the domestic law may turn out to be confusing and vague.

82 See link 2 and 7.

83 See link 5 .

${ }^{84}$ See link 4.

85 See link 1. 


\section{LITERATURE}

Ambos, Kai, 'Judicial Creativity at the Special Tribunal for Lebanon: Is There a Crime of Terrorism under International Law' (2011) 3 Leiden Journal of International Law 655-75.

Bassiouni, M. Cherif, 'Historical Survey: 1919-1998' in Bassiouni, M. Cherif (ed), International Criminal Law, vol 3 (2nd edn, Transnational Publishers, Inc. 1999) 597-634.

Bassiouni, M. Cherif, 'Legal Control of International Terrorism: A Policy Oriented Assessment' (2002) 43 (1) Harvard International Law Journal 83-103.

Broomhall, Bruce, 'Article 22' in Triffterer, Otto (ed), Commentary on the Rome Statute of the International Criminal Court - Observers' Notes, Article by Article (2nd edn, $\mathrm{CH}$ Beck 2008) 713-29.

Cassese, Antonio, 'Terrorism is Also Disrupting Some Crucial Legal Categories of International Law' (2001) 5 European Journal of International Law 993-1001.

Clark, Roger S., 'Article 121' in Triffterer, Otto (ed), Commentary on the Rome Statute of the International Criminal Court - Observers' Notes, Article by Article (2nd edn, CH Beck 2008) 1751-57.

Cohen, Aviv, 'Prosecuting Terrorists at the International Criminal Court: Reevaluating an Unused Legal Tool to Combat Terrorism' (2012) 2 Michigan State International Law Review 219-57.

Corrales Hoyos, Mateo, 'Including the Crime of Terrorism Within the Rome Statute: Likelihood and Prospects' (2017) 1 Global Politics Review 25-38.

Cryer, Robert, Friman, Hakan, Robinson, Darryl and Wilmshurst, Elizabeth, An Introduction to International Criminal Law and Procedure (CUP 2010)

Dixon, Rodney (Revised by Christopher Hall), 'Analysis and interpretation of elements: Paragraph I: List of crimes: Chapeau' in 'Article 7' in Triffterer, Otto (ed), Commentary on the Rome Statute of the International Criminal Court - Observers' Notes, Article by Article (2nd edn, CH Beck 2008) $168-83$.

Dörmann, Knut, 'Paragraph 2: Meaning of "War Crimes"' in 'Article 8' in Triffterer, Otto (ed), Commentary on the Rome Statute of the International Criminal Court-Observers' Notes, Article by Article (2nd edn, CH Beck 2008) 300-22.

Ferencz, Benjamin B., An International Criminal Court - A Step Toward World Peace. A Documentary History and Analysis, vol 1 (Oceana Publications, Inc. 1980).

Hall, Christopher K., 'Introduction/General Remarks' in 'Article 7' in Triffterer, Otto (ed), Commentary on the Rome Statute of the International Criminal Court-Observers' Notes, Article by Article (2nd edn, CH Beck 2008) 166-67.

Hoc, Stanisław, 'Artykuł 141' [Article 141] in Filar, Marian (ed), Kodeks karny. Komentarz [Criminal Code. A Commentary] (Wolters Kluwer Polska 2014) 910-16.

Junod, Sylvie-So, Commentary on the Protocol Additional to the Geneva Conventions of 12 August 1949, and relating to the Protection of Victims of Non-International Armed Conflicts (Protocol II) (Martinus Nijhoff Publishers 1987)

Kalitowski, Michał, Artykuł 258 [Article 258] in Filar, Marian (ed), Kodeks karny. Komentarz [Criminal Code. A Commentary] (Wolters Kluwer Polska 2014) 1447-450.

Kiziński, Miłosz, 'Wybrane aspekty prawnokarne służby obywatela polskiego w obcym wojsku lub w obcej organizacji wojskowej (art. $141 \S 1$ i 3 k.k.)' [Some criminal law aspects of the service of the Polish national in foreign army of military organization (art. $141 \S 1$ and 3 of the Criminal Code] 2006 (1) Wojskowy Przegląd Prawniczy 37-43.

Nowak, Celina, 'The internationalization of the Polish criminal law: how the Polish criminal law changed under the influence of globalization' (2013) 2 Crime, Law and Social Change 139-56.

Pellet, Alain, 'Non, ce n'est pas la guerre' (21 Septembre 2001) Le Monde 12.

Saul, Ben, 'Legislating from a Radical Hague: The United Nations Special Tribunal for Lebanon Invents an International Crime of Transnational Terrorism' (2011) 3 Leiden Journal of International Law 677-700.

Schabas, William A., 'Is Terrorism a Crime Against Humanity?' (2004) 8 (1) Journal of International Peacekeeping 255-61.

Schrijver, Nico, 'Responding to International Terrorism: Moving the Frontiers of International Law for “Enduring Freedom”?' (2001) 3 Netherlands International Law Review 271-91. 
Sońta, Cezariusz, 'Przestępstwo o charakterze terrorystycznym w prawie polskim' [Terrorist offence under Polish law] (2005) 4 Wojskowy Przegląd Prawniczy 3-25.

van den Herik, Larissa, 'The decline of customary international law as a source of international criminal law' (2014) Grotius Centre Working Paper 038-ICL 1-18.

van der Vyver, Johan David, 'Prosecuting Terrorism in International Tribunals' (2010) 24 Emory International Law Review 527-47.

Ventura, Manuel J., 'Terrorism According to the STL's Interlocutory Decision on the Applicable Law: A Defining Moment or a Moment of Defining' (2011) 5 Journal of International Criminal Justice $1021-42$.

Wiak, Krzysztof, 'Artykuł 115' [Article 115] in Grześkowiak, Alicja and Wiak, Krzysztof (eds), Kodeks karny. Komentarz [Criminal Code. A Commentary] (CH Beck 2015) 713-69.

Zgorzały, Robert, 'Przestępstwo o charakterze terrorystycznym w polskim prawie karnym' [Terrorist offence under Polish criminal law] 2007 (7-8) Prokuratura i Prawo 58-79.

Zimmermann, Andreas, 'Article 5' in Triffterer, Otto (ed), Commentary on the Rome Statute of the International Criminal Court - Observers' Notes, Article by Article (2nd edn, CH Beck 2008) $129-42$.

\section{LINKS}

1. ABW zatrzymała członka ISIS [Internal Security Agency arrested the ISIS member] $(2018)<\mathrm{http} / / /$ fakty.interia.pl/polska/news-abw-zatrzymala-czlonka-isis,nId,2553889> accessed 1 November 2018.

2. Prokuratura: Polak należał do grupy terrorystycznej. Brał udział w szkoleniu w Syrii [Prosecutor's office: Polish belonged to a terrorist group. He took part in the training in Syria] (2015) $<$ http://www.tvn24.pl/lodz,69/walczyl-po-stronie-isis-dzis-uslyszy-zarzuty,594838.html> accessed 1 November 2018.

3. Global Terrorism Index 2017. Measuring and understanding the impact of terrorism (2017) $<$ http:/visionofhumanity.org/app/uploads/2017/11/Global-Terrorism-Index-2017.pdf $>$ accessed 1 November 2018.

4. Terroryści czy niewinni ludzie? Mowy końcowe w procesie Czeczenów oskarżonych o pomoc ISIS [Terrorists or innocent people? Final speeches in the trial of Chechens accussed of assisting ISIS] (2017) <http://www.bialystokonline.pl/terrorysci-czy-niewinni-ludzie-mowy-koncowe-wprocesie-czeczenow-oskarzonych-o-pomoc-isis,artykul,100402,14,1.html $>$ accessed 1 November 2018.

5. Pierwszy taki proces w Polsce. Oskarżony o islamski terroryzm w łódzkim sądzie [First this kind of trial in Poland. Accussed of Islamic terrorism in the court in Łódź] (2017) <http://lodz. wyborcza.pl/lodz/7,35136,22614602,polak-islamskim-terrorysta-pierwszy-taki-proces-w-polsce. html> 1 November 2018.

6. Terrorism (2018) <https://ourworldindata.org/terrorism> accessed 1 November 2018.

7. Śledczy rozszerzyli zarzuty wobec Polaka, który walczył w szeregach ISIS [Prosecutors extended the charges against Polish who fought for ISIS] (2015) <http://www.rmf24.pl/raporty/raportswiat-kontra-panstwo-islamskie/najnowsze-fakty/news-sledczy-rozszerzyli-zarzuty-wobecpolaka-ktory-walczyl-w-sze,nId,1917168> accessed 1 November 2018. 